\title{
Prevention and Repression of Illicit Trade in Tobacco Products: Experience of Slovakia
}

\author{
Libor Klimek
}

\section{Contents}

1 National Legal Framework Related to Illicit Trade in Tobacco Products .............. 254

1.1 Substantive Law Issues ............................................ 254

1.1.1 Combatting Illegal Smuggling of Tobacco Products ................. 254

1.2 Application of $n e$ bis in idem Principle ................................ 257

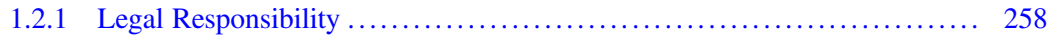

1.2.2 Disposal or Destruction of Confiscated Tobacco Products .............. 260

1.3 Slovak Republic and WTO Framework Convention on Tobacco Control

and the 2012 Protocol to the Framework Convention on Tobacco Control ....... 260

2 Procedural Law Issues .................................................... 261

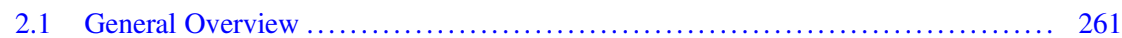

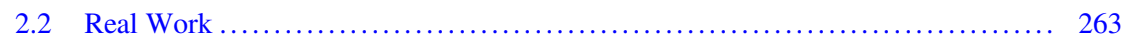

2.3 Specific Procedural Issues Regarding Investigation and Prosecution of Illegal Trade

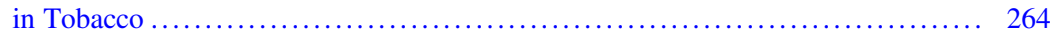

2.4 Special Investigative Techniques Which May Be Used with Regard to Investigations of Illegal Trade in Tobacco .......................... 266

2.5 Preventive Measures That Are Applied in Criminal Proceedings with Regard

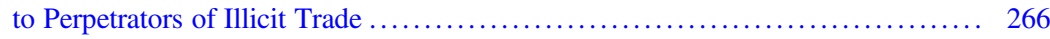

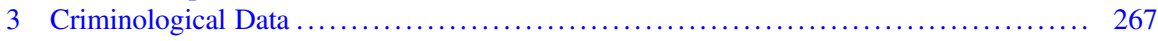

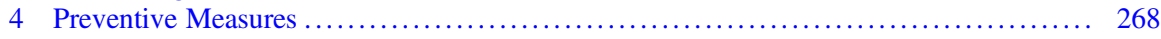

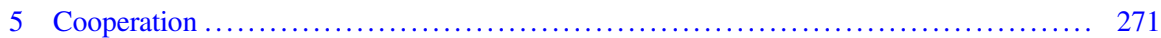

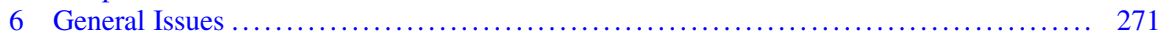

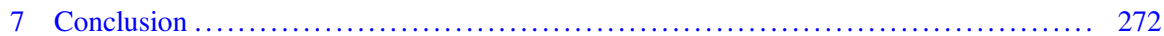

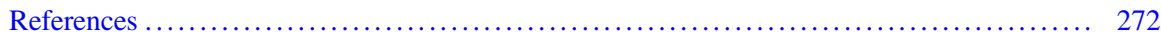

\begin{abstract}
Illegal smuggling with tobacco products as well as trafficking in drugs are crucial problems of modern society, including the Slovak Republic. The chapter deals with the theoretical and applicable issues of the Illegal smuggling with tobacco products in the Slovak Republic. It is divided into three sections. The first section is focused on national legal framework related to illicit trade in tobacco products.
\end{abstract}

\footnotetext{
L. Klimek (ه)

Matej Bel University, Faculty of Law, Department of Criminal Law, Criminology,

Criminalistics and Forensic Disciplines, Banská Bystrica, Slovak Republic

e-mail: libor.klimek@umb.sk
} 
While the second section is focused on criminological data, the last third section is focused on preventive measures.

\section{National Legal Framework Related to Illicit Trade in Tobacco Products}

\subsection{Substantive Law Issues}

\subsubsection{Combatting Illegal Smuggling of Tobacco Products}

Illegal smuggling of tobacco products as well as trafficking in drugs are crucial problems of modern society, including the Slovak Republic. ${ }^{1}$ Combatting the illegal smuggling of tobacco products in the Slovak Republic is a threefold system-the application of tax law, the application of criminal law and the application of administrative law. At the outset, it should be noted that the reality shows that illegal smuggling of tobacco products is investigated in major cases according to tax law by customs officers as an administrative offence under Act No. 106/2004 Coll. on Excise Duty on Tobacco Products (details below).

\subsubsection{Tax Law (Applicable in the Majority of Cases)}

The special law regulating taxes in the area of tobacco products is Act No. 106/2004 Coll. on Excise Duty on Tobacco Products. ${ }^{2}$ This Act regulates excise taxation on tobacco products; moreover, it regulates special provisions on administrative offences.

Illegal smuggling of tobacco products is prohibited under Articles 40 and 41a of the Act No. 106/2004 Coll. on Excise Duty on Tobacco Products.

Under Article 41 entitled "Administrative offenses", an administrative offense is committed by a person authorised to do business if this person (among others):

- is not in a position to demonstrate, in accordance with the law, the origin or method of acquiring the tobacco products found in his/her possession, whether or not he/she handles tobacco products as his/her own;

- is unable to demonstrate, in accordance with that law, the origin or method of acquiring the tobacco raw material found in his/her possession, whether or not it is in its own right, whether or not he/she handles tobacco raw material;

- produces tobacco products without permission to operate a tax warehouse.

\footnotetext{
${ }^{1}$ Holcr et al. (2008), p. 294.

${ }^{2}$ Slovak: Zákon Národnej rady Slovenskej republiky č. 106/2004 Z. z. o spotrebnej dani z tabakových výrobkov v znení neskorších predpisov.
} 
In all cases the Customs Office shall impose a fine for this offense from $€ 100$ to $€ 1,000,000$. In determining the amount of the fine, the Customs Office shall take into account the seriousness, duration and consequences of the illegal conduct.

Under Article 41a entitled "Offenses", an offense is committed by a natural person who is not entitled to do business if he/she (among others):

- sells, offers for sale, stores or transports consumer packaging of tobacco products that are not marked in accordance with this Act and special law (i.e. the Decree of the Ministry of Finance of the Slovak Republic No. 254/2014 Coll., laying down the particulars, preparation and price of a control mark intended for labelling consumer packaging of tobacco products ${ }^{3}$ );

- marks consumer packaging of tobacco products with counterfeit control marks;

- is not in a position to demonstrate, in accordance with the law, the origin or mode of acquisition of tobacco products found in his/her possession, whether or not he/she handles tobacco products as his/her own;

- is unable to demonstrate, in accordance with the law, the origin or method of acquiring the tobacco raw material found in his/her possession, whether or not it is in its own right, whether or not he/she handles tobacco raw material;

- is not able to demonstrate, in accordance with that law, the origin or method of acquiring a smokeless tobacco product found in his/her possession, or whether or not it is a smokeless tobacco product.

For the above-mentioned offenses, the Customs Office shall impose a fine from $€ 50$ to $€ 50,000$. Similarly, in determining the amount of the fine, the Customs Office shall take into account the seriousness, duration and consequences of the illegal conduct.

\subsubsection{Criminal Law}

Illegal smuggling of tobacco products is addressed by the Criminal Code No. 300/2005 Coll. ${ }^{4}$ Illegal smuggling of tobacco products is prohibited under Article 279 of the Criminal Code entitled "Violation of Regulations on State Technical Measures on Marking Goods", which stipulates that any person with control marks, control tapes or other technical control measures to identify goods for tax purposes or for other purposes stipulated by law shall, in contravention of the generally binding legal regulations, intend to cause other damage or to obtain for themselves or others an unlawful benefit or who, in a manner inconsistent with generally binding legal regulations, imports, exports, transports, puts into circulation

\footnotetext{
${ }^{3}$ Slovak: Vyhláška Ministerstva financií Slovenskej republiky č. 254/2014 Z. z., ktorou sa ustanovujú náležitosti, vyhotovenie a cena kontrolnej známky určenej na označovanie spotrebitel'ského balenia tabakových výrobkov.

${ }^{4}$ Slovak: Zákon Národnej rady Slovenskej republiky č. 300/2005 Z. z., Trestný zákon v znení neskorších predpisov.
} 
or stores goods without control marks, control tapes or without other technical control measures for its labelling for tax purposes or for other purposes stipulated by law shall be punished with imprisonment of 6 months to 3 years. This crime can by committed only intentionally. ${ }^{5}$

Further, the offender shall be subject to a term of imprisonment of 1-5 years if he/she commits the above-mentioned offense in special circumstances, namely if he/she caused greater damage, ${ }^{6}$ or with a specific motive, or by a more serious procedure.

Furthermore, the offender shall be liable for a term of imprisonment of 3-8 years if he/she commits the above-mentioned offence causing large-scale damage, or as a member of a dangerous group.

\subsubsection{Administrative Law}

Measures combatting illegal smuggling of tobacco products by administrative law are rarely applicable, but possible some cases. This is stipulated by Act No. 372/1990 Coll. on Offences (i.e. Act on Administrative Offences). ${ }^{7}$ Illegal smuggling of tobacco products is prohibited under Article 30(1) of the Act No. 372/1990 Coll. on Offences (i.e. on Administrative Offences) entitled "Offenses in the Area of Protection Against Alcoholism and Other Toxicants", which stipulates that an offense has committed by the offender if he/she:

(a) sells, facilitates or otherwise allows the consumption of alcoholic beverages to a person who is clearly affected by an alcoholic beverage or other addictive substance, a person under the age of eighteen, or a person who knows that he or she will engage in labour or any other activity that could endanger human health or property;

(b) sells, facilitates or otherwise allows another person to engage in the harmful use of an addictive substance other than alcohol;

\footnotetext{
${ }^{5}$ Klátik et al. (2018), p. 179; Ivor et al. (2017), p. 257.

${ }^{6}$ Under Article 124 of the Criminal Code for criminal law purposes the term damage shall mean damage to property or a real loss of property or rights of the injured party, or any other damage that is causally related to the offense, regardless of whether it is damage to property or rights. Moreover, damage shall mean also obtaining a benefit in a causal relationship with a criminal offense. In addition, damage shall mean also damage to profits which would otherwise be injured or otherwise justified by the circumstances. Under Article 125 of the Criminal Code minor damage means damage exceeding €266; larger damage is an amount of at least ten times that amount; significant damage shall mean an amount of at least 100 times that amount; large-scale damage shall mean an amount of at least five times that amount. These considerations apply equally to determining the amount of the benefit, the value of the case and the extent of the act. If, in a particular part, the Criminal Code requires damage to be caused as a material fact/material consequence of the offense and does not state its amount, it shall be deemed to be at least minor damage.

${ }^{7}$ Slovak: Zákon Národnej rady Slovenskej republiky č. 372/1990 Zb. o priestupkoch v znení neskorších predpisov.
} 
(c) is not subject to a measure affecting the excessive consumption of alcoholic beverages or the use of other addictive substances;

(d) deliberately produces spirit or distillate without permission, or delivers or puts into circulation spirit or distillate produced without authorization;

(e) deliberately allows an alcoholic drink or other addictive substance to be consumed by a person under the age of eighteen if it is threatening that person's physical or moral development;

(f) consumes an alcoholic beverage or another addictive substance, even though he/she knows that he/she will be engaged in labour or any other activity that could endanger human health or damage property;

(g) performs the activity referred to in point (f) upon consumption of an alcoholic beverage or the use of another addictive substance;

(h) in a state of intoxication which he/she has brought about by consuming an alcoholic beverage or by using another addictive substance, he/she performs the activity referred to in point (f).

For an offense under sections (a)(b)(c)(d)(f), a fine may be imposed of up to SKK 3000 (approx. €100); for (e)(g) a fine of up to SKK 5000 (approx. €166) and for an offense under paragraph 1(h) a fine of up to SKK 10,000 (approx. €333); a ban on activities up to 6 months may be imposed for an offense under paragraph 1(f), a ban on activities up to 1 year for an offense under paragraph $1(\mathrm{~g})$ and a ban on activities up to 2 years for the offense referred to in paragraph $1(\mathrm{~h})$.

\subsection{Application of ne bis in idem Principle}

The principle of ne bis in idem is applicable at both national and international (European) level. ${ }^{8}$ The decision of which law is applicable in an administrative or criminal investigation is a matter for the competent officers. In principle, if somebody has been investigated under the administrative law system, there is no possibility to investigate that person for the same act under the criminal law system; if somebody has been investigated under the criminal law system, there is no possibility to investigate that individual for the same act under the administrative law system. This principle is applicable only in the same case, but in a new case an alternative system can be applied.

If the perpetrators of illicit trade of tobacco products are investigated under criminal law rules, they may be investigated as well for fraud, corruption, possession of proceeds obtained from crime, association in an organised criminal group, money laundering, or unauthorised business.

Naturally, each case is individual. One could not state that all perpetrators of illicit trade in tobacco products are investigated for the above-mentioned crimes, but in

${ }^{8}$ Ivor et al. (2013), p. 132; Klimek (2017), p. 130. 
individual cases it is possible. For example, the perpetrators bribe customs officers, or they are members of an organised criminal group.

\subsubsection{Legal Responsibility}

\subsubsection{Legal Responsibility of Individuals: Administrative Law Perspective}

Administrative law responsibility of individuals in the case of illegal smuggling of tobacco products is set out by the Act No. 372/1990 Coll. on Offences. This act is a general act (lex generalis) regulating the responsibility of individuals for administrative offences, since it is a general law regulating conditions for the commission of all administrative offences defined in this Act, as well as in all special acts defining other administrative offences. In comparison to criminal law, where all crimes are defined only in the Criminal Code, in administrative law Act No. 372/1990 Coll. on Offences is the general act, and in addition to this Act there exist many special administrative acts defining special administrative offences; all special acts-including the Act No. 106/2004 Coll. on Excise Duty on Tobacco Products, which provides for administrative offences-follow the rules on administrative responsibility of individuals as defined in the Act No. 372/1990 Coll. on Offences.

As regards individuals, according to the Act No. 372/1990 Coll. on Offences, there are two conditions for committing an administrative offence under all administrative acts in the Slovak Republic:

- the age of 15 years or above; and

- competency (i.e. competency at the time of commission of the offence).

Responsibility for administrative offense is assessed under the law effective at the time of the commission of the offense; it can be considered under a later law only if that law is more favourable for the offender (the same principle applies in the criminal law system). Under the Act No. 106/2004 Coll. on Excise Duty on Tobacco Products, negligence is a satisfactory condition for responsibility for the abovementioned offences.

\subsubsection{Legal Responsibility of Individuals: Criminal Law Perspective}

Criminal law responsibility of individuals in respect of illegal smuggling of tobacco products is set out by the Criminal Code No. 300/2005 Coll. The Criminal Code is the only national law defining all crimes and criminal responsibility of individuals in the Slovak Republic.

As regards individuals, according to the Criminal Code, there are two conditions for committing crime under Article 279 of the Criminal Code, i.e. Violation of Regulations on State Technical Measures on Marking Goods: 
- the age of 14 years or above; it should be noted that a juvenile younger than 15 years of age who, at the time of the offense, has not attained a level of intellectual and moral maturity sufficient to recognise the illegality of or exercise control over his/her conduct is not responsible for his/her act; and

- competency (i.e. competency at the time of commission of the act).

In comparison to other crimes in the Criminal Code, the above-mentioned conditions are applicable to all crimes, except for one entitled Sexual Abuse (the Criminal Code requires the age of 15 years or above). ${ }^{9}$

Responsibility for a crime is assessed under the law effective at the time of the commission of the act; it can be considered under a later law only if that law is more favourable for the offender (the same principle applies in the administrative law system). The Criminal Code requires intentional commission of the crime defined in Article 279.

\subsubsection{Legal Responsibility of Legal Persons: Administrative Law Perspective}

In general, administrative responsibility of legal persons exists in the legal system of the Slovak Republic. A legal person is responsible for the conduct of its employees, members, statutory representatives, etc. within the scope of its tasks. This applies to all administrative delicts, including the above-mentioned administrative delicts. The condition for administrative responsibility of legal persons is delinquency, which is associated with its establishment and existence.

There is a practical problem. Any legal person, in particular commercial companies, may deliberately avoid responsibility for committed administrative offenses, and in consequence avoid sanctions. It can convert, for example, in the form of a merger. It may be the case that the same or partially same circle of persons (owners, shareholders, persons in statutory bodies) continues to operate with the same property as a new legal entity.

\subsubsection{Legal Responsibility of Legal Persons: Criminal Law Perspective}

In general, criminal responsibility of legal persons exists in the legal system of the Slovak Republic (the Slovak Republic was one of the last European Union Member States to introduce it). As stated above, their criminal responsibility is regulated by a special law-the Act No. 91/2016 Coll. on Criminal Responsibility of Legal Persons. ${ }^{10}$ This act contains a list of crimes under the Criminal Code for which legal persons as well can be responsible under criminal law. However, the list does not

\footnotetext{
${ }^{9}$ Klátik et al. (2018), p. 105; Ivor et al. (2017), p. 135.

${ }^{10}$ Záhora and Šimovček (2019), p. 17.
} 
include Article 279 of the Criminal Code, i.e. Violation of Regulations on State Technical Measures on Marking Goods. Indeed, in the Slovak Republic, responsibility for the above-mentioned crime in the case of legal persons is not possible; it only applies in the case of individuals.

\subsubsection{Disposal or Destruction of Confiscated Tobacco Products}

Destruction of confiscated tobacco products is simple-the Slovak Republic employs incineration (burning out) of confiscated tobacco products in so-called incineration houses.

Seized tobacco products shall be incinerated (burned out) in special incineration houses under the control of a special committee. One such house is located in Košice (the second largest city in the Slovak Republic). For example, in October 2016, customs officers in Košice burned out over 430,000 seized cigarettes with a total weight of $570 \mathrm{~kg}$ and valued at $€ 66,244$. The seized cigarettes were mostly the subject of smuggling, revealed by customs officers in the exercise of customs supervision.

On the other hand, there are many problems. For example, some officers "steal" seized tobacco products and smoke them, or even sell them.

\subsection{Slovak Republic and WTO Framework Convention on Tobacco Control and the 2012 Protocol to the Framework Convention on Tobacco Control}

The Slovak Republic is a party to the Framework Convention on Tobacco Control of 2003. It was signed on 19 December 2003 and ratified on 4 May 2004. It is established in national law as Decree No. 84/2005 Coll.

As regards the Protocol to the Framework Convention on Tobacco Control of 2012, the President of the Slovak Republic signed accession to the Protocol on 19 July 2017. The Protocol was opened for signatures from 10 January 2013 to 9 January 2014 and was signed by 53 States as well as the European Union. The Slovak Republic did not sign the protocol within the set deadline, but pursuant to Article 44(1) of the Protocol "it shall be open for accession from the day after the date on which the Protocol is closed for signature". The protocol was ratified by the Slovak Republic on 25 September 2017. It is established in national law as Decree No. 255/2018 Coll.

It should be noted that according to Article 7(4) of the Constitution of the Slovak Republic No. 460/1992 Coll., ${ }^{11}$ the Framework Convention on Tobacco Control of

\footnotetext{
${ }^{11}$ Slovak: Zákon Slovenskej národnej rady č. 460/1992 Zb., Ústava Slovenskej republiky v znení neskorších predpisov.
} 
2003 as well as the Protocol to the Framework Convention on Tobacco Control of 2012 are international treaties, the implementation of which requires national law, and therefore in accordance with Article 86(d) of the Constitution they were subject to the approval of the National Council of the Slovak Republic and subsequent ratification by the President of the Slovak Republic.

In principle, Slovak national law is aligned with the requirements set forth in the above-mentioned documents. Since the Protocol to the Framework Convention on Tobacco Control of 2012 is ratified as international treaty, its provisions are recognised in Slovak national law, including definitions stipulated in Article 14 entitled "Unlawful conduct including criminal offences". On the other hand, Slovak national practice accepts, primarily, only definitions of crimes as set out in the Criminal Code. However, the Criminal Code does not follow (i.e. does not "copy") the provisions contained in Article 14 of Protocol to the FCTC of 2012.

\section{Procedural Law Issues}

\subsection{General Overview}

The most important body in the Slovak Republic combatting illicit trade in tobacco products is the Financial Administration of the Slovak Republic. ${ }^{12}$

The main task of the Financial Administration of the Slovak Republic is to efficiently collect and administer customs duties and taxes in the Slovak Republic and to protect the economic interests of the State. Its special tasks are based on the programme of the Government of the Slovak Republic, the Program Declaration of the Government of the Slovak Republic and the strategic intentions of the Ministry of Finance of the Slovak Republic. The Financial Administration of the Slovak Republic shall:

- perform the tasks arising from the main mission of financial administration, in

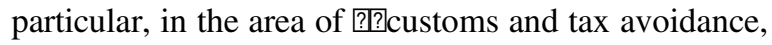

- supervise compliance with generally binding EU legislation and international agreements to ensure the implementation of trade policy, customs policy, tax policy and common agricultural policy in the circulation of goods in contact with third States;

- perform customs supervision of goods within the customs territory of the EU, in the field of indirect tax administration, tax supervision of excise goods;

- perform mutual international assistance and cooperation in the management of customs and taxation and in the recovery of financial claims;

\footnotetext{
${ }^{12}$ Slovak: Finančná správa Slovenskej republiky.
} 
- perform tasks in the areas of customs tariffs, customs value, nomenclature classification of goods, origin of goods, statistics of trade with third countries and trade between EU Member States; and

- perform other tasks laid down by specific regulations.

The Financial Administration of the Slovak Republic was established on 1 January 2012 by merging the former customs administration and tax administration. Its establishment was preceded by approval of the reform of the customs administration and the tax administration with a view to unifying the collection of taxes, customs and insurance contributions through the UNITAS program, which was initiated in 2008 by the adoption of the Resolution of the Government of the Slovak Republic No. 285/2008 of 7 May 2008 on the Concept of Tax and Customs Reform.

The legal basis of the Financial Administration of the Slovak Republic is the Act No. 333/2011 Coll. on State Administration Bodies in the Area of Taxes, Fees and Customs. ${ }^{13}$ Under this Act, the Financial Administration of the Slovak Republic ensures the performance of tasks in accordance with: first, the Act No. 333/2011 Coll. on State Administration Bodies in the Area of Taxes, Fees and Customs and Act No. 479/2009 Coll. on State Administration Bodies in the Field of Taxes and Fees; second, the Act No. 652/2004 Coll. on State Administration Bodies in Customs; third, other generally binding legal regulations; and, fourth, international agreements by which the Slovak Republic is bound.

The Financial Administration of the Slovak Republic is structured thus:

- the Financial Directorate of the Slovak Republic-whose headquarters is in Banská Bystrica (a city in the central part of the Slovak Republic); its statutory body is the President, which is its director/manager, and he/she is responsible to the Minister of Finance of the Slovak Republic;

- Customs Offices; ${ }^{14}$

- Tax Offices; ${ }^{15}$ and

- the Criminal Office of the Financial Administration. It is headquartered in Bratislava (the capital of the Slovak Republic). The Director is in charge of the Criminal Office-he/she is responsible to the President of the Financial Administration of the Slovak Republic.

According to Article 5 of the Act No. 333/2011 Coll. on State Administration Bodies in the Area of Taxes, Fees and Customs the competences Criminal Office of the Financial Administration are (among others):

\footnotetext{
${ }^{13}$ Slovak: Zákon Národnej rady Slovenskej republiky č. 333/2011 Z. z. o orgánoch štátnej správy v oblasti daní, poplatkov a colníctva v znení neskorších predpisov.

${ }^{14}$ See list of all Customs Offices available online <https://www.financnasprava.sk/sk/kontakt/ kontakty-na-urady $>$.

${ }^{15}$ See list of all Tax Offices available online $<$ https://www.financnasprava.sk/sk/kontakt/kontaktyna-urady $>$.
} 
- it shall execute the tasks of a central coordination unit and other tasks deriving from international agreements,

- it shall execute tasks in the fight against the illicit import, export and transit of narcotic drugs, psychotropic substances, their precursors, protected plant species, animals and specimens, against the illicit transport of radioactive materials and other highly hazardous materials, if the detection of persons are in any way involved in offenses committed in the field of narcotic drugs, psychotropic substances, their precursors and protected species of plants, animals and specimens in connection with their import, export or transit;

- it shall execute customs supervision in agreement with the authorities of other States, with escorts or other classified means of surveillance, if it is reasonable to assume that the consignment contains narcotics, psychotropic substances, their precursors, tobacco, tobacco products, protected plant species, animals and specimens for which there is no relevant authorisation or other possession of which special permission is required, goods suspected of being involved in the commission of a tax or customs offense, items intended to commit an offense or a criminal offense, or where international contact is necessary in order to identify persons who are involved in the handling of the shipment; if the information thus obtained is to serve as evidence in criminal proceedings, it is based on the rules of international cooperation of judicial authorities in criminal matters;

- it shall execute cross-border surveillance and cross-border persecution to the extent and under the conditions laid down by a special regulation and international treaty;

- it shall execute tasks in the field of detection and investigation of crimes committed in connection with violations of value added tax legislation on imports and excise duties or customs regulations and the detection of their perpetrators;

- it shall ensure the safety of the transport of seized goods, perform escorts of detained or remanded persons suspected of committing a crime.

\subsection{Real Work}

Every fourteenth cigarette in the Slovak Republic is illegal. Indeed, the Financial Administration of the Slovak Republic and its bodies have too much work to do.

As regards illicit trade in tobacco products, while it was only $1 \%$ in 2014 , it increased to $6 \%$ in 2018. Consumers in the Slovak Republic do not realise that it is precisely this kind of source that criminal groups use to fund their illegal activities.

According to information collected by the Financial Administration of the Slovak Republic on the fight against illegal cigarettes, more than 2.2 million cigarettes were seized directly at the eastern border with Ukraine in 2015-worth €66,000. These are just cigarettes from Ukraine without EU valid stamps. In 2016 it was considerably less -1.2 million cigarettes worth $€ 38,000$. Since the beginning of 2019 , over 400 cases on the eastern border with Ukraine have been identified, in which officers have seized more than 1.3 million illegal cigarettes. "We know from practice that 
cigarettes are the most common commodity. In the east of Slovakia they are a smuggling classic", explained Tomáš Prochocký, General Director of the Customs Financial Administration. He added that "customs officers in the field are confronted with truly inventive smuggling shelters, in tires, bicycle frames, pastries, juices, wooden boards, metal pipes . . . but with years of experience and convenient modern technology, we can uncover these hiding places. Especially on the eastern border our work is very important, because we protect the security and interests of the citizens of the whole EU'. 16

However, the fight against illegal cigarettes is not just about smuggling cigarettes from Ukraine to Slovakia. In fact, the Slovak Republic has already identified several cases of illegal production in Slovakia. "We have had a number of successful interventions against illegal cigarette production. Only this year [2019] we prevented almost 30 million illegal cigarettes, 30 tons of tobacco and thousands of cigars from reaching the European market. In addition, we also made raids in two factories and seized complete cigarette production lines. Indeed, we destroyed the perpetrators' illegal business" said L'udovít Makó, Director of the Criminal Office of the Financial Administration. He also explained: "The Slovak Republic is a transit country for illegal cigarettes. Most illegal cigarettes go further to Europe - to the UK, Germany, Poland or the Czech Republic."17

In addition, even the illegal production of cigarettes in the Slovak Republic with the use of illegally imported tobacco is not exceptional. For example, in 2016 customs officers seized more than 2 tonnes of tobacco, from which 2.3 million cigarettes could be produced. The tax evasion would have amounted to $€ 170,000$. Such cigarettes are generally more dangerous than regular cigarettes.

\subsection{Specific Procedural Issues Regarding Investigation and Prosecution of Illegal Trade in Tobacco}

The competent body for investigations in the majority cases is the Financial Administration of the Slovak Republic-its Criminal Office of the Financial Administration.

The Act No. 333/2011 Coll. on State Administration Bodies in the Area of Taxes, Fees and Customs does not regulate special provisions on procedural rules and investigations; in Article 8, it "only" states that investigator(s) shall respect the Constitution of the Slovak Republic, national law, ratified international agreements,

\footnotetext{
${ }^{16}$ Až každá štrnásta cigareta na Slovensku je nelegálna [online] (translation - Every fourteenth cigarette in Slovakia is illegal). Available <https://www.financnasprava.sk/sk/pre-media/novinky/ archiv-noviniek/detail-novinky/_fejky-cig-ts $>$.

${ }^{17}$ Nelegálne cigarety [online] (translation - Illegal Cigarettes). Available $<$ https://www.szzv.sk/azkazda-strnasta-cigareta-na-slovensku-je-nelegalna-na-vychodnom-dokonca-kazda-tretia/ $>$.
} 
etc. Special rules are regulated by so-called "internal law", i.e. law adopted by the Financial Administration of the Slovak Republic for its own "internal" purposes.

The Criminal Office of the Financial Administration has special investigators, i.e. investigators of the Criminal Office of the Financial Administration. In accordance with Article 10(b) of the Criminal Proceedings Code, he/she is a customs officer who has been appointed as a financial administration investigator by the Minister of Finance of the Slovak Republic. Such investigators carry out investigations into crimes committed in connection with violations of customs or tax regulations within the scope of customs administration, as well as offenses committed in connection with customs or tax violations.

The Criminal Office of the Financial Administration can set up a special group called an itinerant group. This is a special group working with technical means. Its mission encompasses urgent actions and one-off cases. The group's exercises are carried out continuously, according to planned schedules for a period of 1 month.

Criminal intelligence activities in the Slovak Republic are connected to combatting illegal smuggling of tobacco products. They are performed by the Slovak Information Service (hereinafter SIS). The SIS is regulated by the Act No. 46/1993 Coll. on the Slovak Information Service. ${ }^{18}$ This Act regulates official provisions on its establishment, tasks, structure, etc., however, there is no operational or procedural information about how it works.

The annual reports of the SIS provide information on results for specific years, but almost all information is vague (no detailed information, no reference numbers of cases, no detailed figures, etc.). As regards illicit trade in tobacco, in the Annual Report of the Slovak Information Service of $2018,{ }^{19}$ we can find the following statements:

- The SIS informed recipients about the distribution of cigarettes produced on illegal routes in western Slovakia. As part of the detection of crime related to the distribution of non-taxed cigarettes, the SIS also received information on the import of smuggled cigarettes into the territory of the Slovak Republic from Ukraine and Hungary.

- The SIS sent information to the relevant national authorities on tax fraud organisers who avoided value added tax (VAT) and corporate income tax through a network of interconnected companies or unduly benefited from excessive VAT deductions. It also involved cigarette smuggling, illegal production and sale of non-taxed spirits, cigarettes and mineral oils.

The SIS also examined suspicions of corruption in the police, courts and financial administration. The relevant knowledge concerned, for example, members of the Police corps who allegedly cooperated with organised crime groups in smuggling

\footnotetext{
${ }^{18}$ Slovak: Zákon Národnej rady Slovenskej republiky č. 46/1993 Z. z. o Slovenskej informačnej službe v znení neskorších predpisov.

${ }^{19}$ Správa o činnosti SIS za rok 2018, Bratislava, 2019. Available online <http://www.sis.gov.sk/ pre-vas/sprava-o-cinnosti-2018.html >.
} 
goods through the Slovak-Ukrainian border in exchange for bribes, provided official information to unauthorised persons and engaged in activities aimed at obstructing related criminal investigations.

\subsection{Special Investigative Techniques Which May Be Used with Regard to Investigations of Illegal Trade in Tobacco}

In practice, electronic surveillance is used, especially along the eastern border with Ukraine, because it is an external border of the Schengen area-the only external border on Slovak territory. However, at night it is difficult to "see" the movement of smugglers. Officers use also special radars.

Many times controlled deliveries have been used, for example in cases of smuggling from Ukraine to the Slovak Republic through the eastern (Slovak-Ukrainian) border. Moreover, it has been used many times in the Schengen area, for example in cooperation with Hungary.

\subsection{Preventive Measures That Are Applied in Criminal Proceedings with Regard to Perpetrators of Illicit Trade}

Under the Criminal Proceedings Code, the taking of funds (money) in bank account (s) is possible; the Code uses the terminology "seizure" (rather than "freezing"). The procedure is regulated by Article 95, which stipulates that if the facts indicate that the funds in an account at the bank or at the branch of a foreign bank or other funds are intended or have been used to commit an offense, or are proceeds of commission of a crime, a judge may issue an order to the prosecutor that the funds shall be seized. The order described in the preceding sentence may also apply to additional funds received to the account, including of accessories, if the reason for detention also applies to them. Seizure cannot apply to funds that are necessary to satisfy the basic living needs of the accused or the person from whom they were seized, to meet the living needs of a person whose upbringing or maintenance they are responsible for, or the person from whom the funds are secured is required by law to look after them.

If there are no longer grounds for seizing the funds, the seizure is revoked. If there are no longer grounds for seizing a specified amount of funds, the seizure shall be limited. The judge and the prosecutor shall decide on the revocation or limitation of the seizure by order.

Seized funds may only be disposed of after the prior written consent of the judge and in the pre-trial proceedings of the prosecutor. If the seizure continues, all legal acts and claims against secured funds are ineffective. The person whose funds were seized has the right to request the revocation or limitation of the procedure. The judge and the prosecutor shall rule without delay on such a request. A complaint is 
admissible against this decision. If the application is rejected, the person whose funds have been seized may, if he/she does not provide other reasons, resubmit it 30 days after the date on which the decision on the previous application entered into force.

Moreover, under the Criminal Proceedings Code it is possible to order a house search. The procedure is regulated by Articles 99 and 100. They stipulate that a house search can be carried out if there is reason to believe that there is a matter of importance in the apartment or other housing serving or in the premises belonging thereto, or that a person suspected of having committed the crime is hiding there, or the securing of movable property to satisfy the injured party's claim for damages. The house search shall be ordered by the judge in pre-trial proceedings on its own initiative or at the request of the prosecutor. The house search shall be carried out without delay by the authority which ordered it, or by a police officer at the authority's command.

In addition, the Criminal Proceedings Code allows for the search of other premises and parcels of land. The procedure is regulated by Article 101, which stipulates that either a judge or the prosecution with the consent of a police officer may order the search of other premises and parcels of land. The order must be issued in writing and must be justified. It shall be delivered to the owner or user of the premises or land or to his/her staff during the search. The search of other premises or land shall be carried out without delay by the authority which ordered it or by a police officer at the authority's command. Without an order or consent, a police officer may only search other premises or land if the order or consent cannot be obtained in advance and the matter cannot be delayed, or if the person is caught in the commission of a criminal offense, or there is an arrest warrant for the person, or the person is believed to be hiding in these areas.

\section{Criminological Data}

In the Slovak Republic there is no free, publicly available database containing criminological information regarding illicit trade in tobacco products.

For example, in 2014 customs officers seized a total of 19,481,493 smuggled cigarettes; the total financial loss for 2014 was calculated at $€ 1,941,440.85$.

The most problematic situation is on the eastern border with Ukraine. In the past, smugglers created a hidden tunnel almost $700 \mathrm{~m}$ long-they dug it without approval underneath the border. All kinds of customs goods were transported, including tobacco products. The tunnel was used for 2 years. The newest method used by smugglers are drones (flying machines) carrying smuggled products across borders.

As regards the characteristics of perpetrators of illicit trade in tobacco products in the Slovak Republic, smugglers come from all social "levels". Many smugglers on the Slovak-Ukrainian border have simple strategies, for example: 
- Groups of friends behave like tourists taking a walk in nature. They cross borders with touristic backpacks, buy tobacco products in Ukraine and walk back to Slovakia through the forest. This is a common procedure.

- Many smugglers have renovated cars to add special compartments for cigarettes. They legally cross the border from Slovakia to Ukraine, legally buy customs goods and then claim that they were shopping for cheaper products in Ukraine. The reality is that they are smuggling hidden tobacco products. This is a common procedure.

Even the husband of a Ukrainian diplomat smuggled tobacco products by car, and at border stated that the car enjoyed diplomatic immunity; indeed, it was not possible to search it. The Slovak authorities contacted Ukrainian central authorities, who allowed to search him and his car, where almost 60,000 packages of cigarettes from Ukraine were found worth approx. €30,000.

\section{Preventive Measures}

Restrictions on tobacco advertising are regulated by Article 6(1) of the Act No. 147/2001 Coll. on Advertising, ${ }^{20}$ which stipulates that the advertising of tobacco products shall be prohibited:

- on all types of informational media;

- through distribution of tobacco products to the public;

- on non-smoking advertising media which are distributed to the public, other than advertising distributed at points of sale of products;

- through tobacco product sponsorship;

- through indication of the trademark, emblem, name or other significant feature of a tobacco product aside from its presentation at points of sale of tobacco products.

As a result, in the Slovak Republic there is almost zero commercial advertising of tobacco products. This approach is welcomed. Supervision of compliance with the cited provisions is carried out by the Slovak Trade Inspection. ${ }^{21}$

Since 2017, special markings of packages are used in the Slovak Republic, i.e. special pictures on packages of cigarettes. They replaced earlier simple written warning on packages, such as "Smoking can kill!". However, even though the packages have disgusting pictures, many people ignore them.

The Financial Administration of the Slovak Republic (details about this body are presented above) initiated the project Don't Smoke Fakes and made the relevant information available online at $<$ https://nekurfejky.sk $>$. It adapted the language on the site to a younger audience so that all information was given clearly and

\footnotetext{
${ }^{20}$ Slovak: Zákon Národnej rady Slovenskej republiky č. 147/2001 Z. z. o reklame v znení neskorších predpisov.

${ }^{21}$ Slovak: Slovenská obchodná inšpekcia.
} 
comprehensibly. The creators of the idea chose the name "Don't Smoke Fakes" ("Nekur fejky") intentionally to attract attention and also because the problem of illegal cigarettes concerns primarily eastern Slovakia, where, according to analyses of the Financial Administration of the Slovak Republic, almost every third package of cigarettes is illegal.

Moreover, the Slovak Republic adopted legislation protecting non-smokers-the Act No. 377/2004 Coll. on the Protection of Non-smokers. ${ }^{22}$ This Act regulates, first, the conditions for protecting people from becoming addicted to nicotine as an addictive and harmful ingredient found in tobacco and tobacco products, from the harmful effects of smoking, and from other uses of tobacco products that harm the health of smokers who are directly exposed to smoke; and second, conditions for protecting people against products intended for smoking and not containing tobacco.

According to Article 7 of the Act No. 377/2004 Coll. on the Protection of Non-smokers smoking is prohibited:

- in public airports, in public passenger rail vehicles, in passenger transport vehicles, in station and stopping areas, waiting rooms, shelters and stops, covered platforms and closed public spaces related to such traffic for passengers, on open platforms within four meters of the defined platform area;

- in health establishments other than reserved smoking areas in psychiatric wards;

- in primary schools, secondary schools and school facilities, pre-school establishments and playgrounds;

- in universities and student hostels;

- in social services establishments other than smokers;

- in theatres, cinemas, exhibition halls, museums, galleries and other cultural establishments, sports facilities and shops;

- in official buildings other than reserved smoking areas;

- in department stores, except in areas that are structurally separate so that no harmful substances from tobacco products nor their smoke and tar from smoking and/or non-tobacco products enter nor pollute publicly accessible department stores;

- in mass catering facilities other than those which have at least $50 \%$ of space reserved for non-smokers in an area that is structurally separate from the smokers' compartment, so that no harmful substances from tobacco products or smoke or tar, nor from products that are intended to be smoked and do not contain tobacco are introduced into the smoke-free area, while the non-smoking area must be located at the entrance to the facility;

- in health care facilities; and

- in areas where juveniles are in custody or serving a custodial sentence.

On top of all the above-mentioned provisions, the Slovak Republic has also implemented European Union legal measures, for example:

\footnotetext{
${ }^{22}$ Slovak: Zákon Národnej rady Slovenskej republiky č. 147/2001 Z. z. 377/2004 Z. z. o ochrane nefajčiarov v znení neskorších predpisov.
} 
- Council Directive 2008/118/EC concerning the general arrangements for excise, ${ }^{23}$

- Council Directive 2011/64/EU on the structure and rates of excise duty applied to manufactured tobacco, ${ }^{24}$

- Council Directive 2007/74/EC on the exemption from value added tax and excise duty of goods imported by persons travelling from third countries ${ }^{25}$ and

- Council Directive 2006/79/EC on the exemption from taxes of imports of small consignments of goods of a non-commercial character from third countries. ${ }^{26}$

All of the above-mentioned directives have been implemented into the Act No. 106/2004 Coll. on Excise Duty on Tobacco Products.

As stated above, the most important body in the Slovak Republic combatting illicit trade in tobacco products is the Financial Administration of the Slovak Republic. There is no special body or institution responsible for prevention of illicit trade in tobacco products, but the Government of the Slovak Republic is the main authority creating strategic prevention plans. It should be noted, as regards the education of youth, the National Institute for Education operates in the Slovak Republic. ${ }^{27}$ Its mission is to continually enhance curricula development based on the results of pedagogical research and the latest scientific knowledge. It provides children and young people with opportunities for their personal development so that they have the cognitive, personal and social skills necessary for their future life and also for lifelong learning. In 2011, it published a prevention-focused book for youth entitled Towards Prevention at School. ${ }^{28}$ The majority of this book is focused on smoking prevention.

\footnotetext{
${ }^{23}$ Council Directive 2008/118/EC of 16 December 2008 concerning the general arrangements for excise duty and repealing Directive 92/12/EEC, as amended by the Directive 2010/12/EU of 16 February 2010. Official Journal of the European Union, L 9/12, 14 January 2009.

${ }^{24}$ Council Directive 2011/64/EU of 21 June 2011 on the structure and rates of excise duty applied to manufactured tobacco. Official Journal of the European Union, L 176/24, 5 July 2011.

${ }^{25}$ Council Directive 2007/74/EC of 20 December 2007 on the exemption from value added tax and excise duty of goods imported by persons travelling from third countries. Official Journal of the European Union, L 346/6, 29 December 2007.

${ }^{26}$ Council Directive 2006/79/EC of 5 October 2006 on the exemption from taxes of imports of small consignments of goods of a non-commercial character from third countries (codified version). Official Journal of the European Union, L 286/15, 17 October 2006.

${ }^{27}$ Slovak: Štátny pedagogický ústav.

${ }^{28}$ Slovak: K prevencii v škole. The book is available online <http://www.statpedu.sk/files/sk/ metodicky-portal/metodicke-podnety/k-prevencii-skole.pdf $>$.
} 


\section{Cooperation}

Slovak Customs Offices cooperate with law enforcement authorities, in particular with police officers. As stated above, the most problematic is the Slovak-Ukrainian border. Indeed, Slovak officers cooperate with Ukrainian officers.

Slovak national institutions cooperate with OLAF (European Anti-Fraud Office), which is a body of the European Union protecting its financial interests.

\section{General Issues}

Young people in particular are of the opinion that smoking cigarettes is a lifestyle question. The majority of them do not have much money. As a consequence, they have a small budget for smoking. Smuggled tobacco products are accessible for them, because they are cheaper. They are a target group for smugglers.

As for adults, many are addicted to smoking - due to stress, social behaviour in groups, etc. Despite the fact that a large selection of cigarette brands offer highquality products on legal markets in shops, there are still people looking for cheaper cigarettes. They are a target group for smugglers as well. On the other hand, the number of people using electronic cigarettes is increasing. In recent years, former "classic smokers" have become "vapers". However, the majority of smokers are still "classic smokers".

In the eastern part of the Slovak Republic the unemployment rate is the highest in the country. People living/residing near the Slovak-Ukrainian border have good access to Ukraine. Taking into account the fact that they have a low standard of living, since they are poor, there is a possibility to "earn" extra money. Of course, not only poor people smuggle illegal tobacco products. There are organised groups specialising in this kind of "undertaking". They "run" a business, but without official approval, since for "smuggling" it is not possible to apply for registration of a commercial company.

The Slovak Republic is one of the smallest Member States of the European Union, and as such, it is only a minor destination for large European organised smuggling groups. Due to the relatively low price of cigarettes compared to Western Europe, organised groups with cigarette contraband mostly transit through the Slovak Republic to markets in Western Europe. For example, while in the Slovak Republic 1 package of cigarettes costs approx. €3.50, the same costs €6-7 in Germany. Indeed, if a large number of cigarette packages are smuggled from Ukraine to the Slovak Republic, which is the point of entry to the Schengen area, it is very easy to transport them to any other Schengen state because of the absence of control at internal borders. 


\section{Conclusion}

A legal framework related to illicit trade in tobacco products exists. Its objective is to combat this phenomenon. However, reality shows that there is much more work to do, since the legal regulation itself is not satisfactory. As we have seen, many people have reasons to buy and use illicit tobacco products.

The best results in combatting illicit trade in tobacco products are achieved by the Financial Administration of the Slovak Republic, in particular the Criminal Office of the Financial Administration. Its work is effective; however, it will never be perfect. Smugglers have effective means of performing their illegal activities, and contrary to the Financial Administration of the Slovak Republic, they are not bound by law. European states, including the Slovak Republic, are aware that their cooperation is of crucial importance. In the case of Slovakia, the most important cooperation is with Ukraine. The Slovak-Ukrainian border is a gateway to the European Union, since the Slovak Republic is often a transit state for illegal cigarettes-most illegal cigarettes go further into Europe.

\section{References}

Až každá štrnásta cigareta na Slovensku je nelegálna [online] [transl.: Every fourteenth cigarette in Slovakia is illegal]. <https://www.financnasprava.sk/sk/pre-media/novinky/archiv-noviniek/ detail-novinky/_fejky-cig-ts $>$.

Holcr K et al (2008) Kriminológia [transl.: Criminology]. Iura edition, Bratislava, 403 pp

Ivor J, Klimek L, Záhora J (2013) Trestné právo Európskej únie a jeho vplyv na právny poriadok Slovenskej republiky [transl.: Criminal Law of the European Union and its impact on the legal order of the Slovak Republic]. Eurokódex, Žilina, $888 \mathrm{pp}$

Ivor J, Polák P, Záhora J (2017) Trestné právo hmotné II - Osobitná čast' [transl.: Substantive criminal law II - special part]. Wolters Kluwer, Bratislava, 648 pp

Klátik J et al (2018) Trestné právo hmotné - Osobitná čast' [transl.: Substantive criminal law special part]. Vydavatelství a nakladatelství Aleš Čeněk, Plzeň, 422 pp

Klimek L (2017) Základy trestného práva Európskej únie [transl.: Fundamentals of the European Union criminal law]. Wolters Kluwer, Bratislava, $265 \mathrm{pp}$

Nelegálne cigarety [online] (transl.: Illegal cigarettes). <https://www.szzv.sk/az-kazda-strnastacigareta-na-slovensku-je-nelegalna-na-vychodnom-dokonca-kazda-tretia/ $>$

Správa o činnosti SIS za rok 2018, Bratislava, 2019. <http://www.sis.gov.sk/pre-vas/sprava-ocinnosti-2018.html>

Záhora J, Šimovček I (2019) Zákon o trestnej zodpovednosti právnických osôb. In: Komentár, vol 2. Wolters Kluwer, Bratislava

Zákon Národnej rady Slovenskej republiky č. 372/1990 Zb. o priestupkoch v znení neskorších predpisov

Zákon Národnej rady Slovenskej republiky č. 46/1993 Z. z. o Slovenskej informačnej službe v znení neskorších predpisov

Zákon Národnej rady Slovenskej republiky č. 147/2001 Z. z. o reklame v znení neskorších predpisov

Zákon Národnej rady Slovenskej republiky č. 147/2001 Z. z. 377/2004 Z. z. o ochrane nefajčiarov v znení neskorších predpisov 
Zákon Národnej rady Slovenskej republiky č. 106/2004 Z. z. o spotrebnej dani z tabakových výrobkov v znení neskorších predpisov

Zákon Národnej rady Slovenskej republiky č. 300/2005 Z. z., Trestný zákon v znení neskorších predpisov

Zákon Národnej rady Slovenskej republiky č. 333/2011 Z. z. o orgánoch štátnej správy v oblasti daní, poplatkov a colníctva v znení neskorších predpisov

Libor Klimek Ph.D., is Associate Professor at the Department of Criminal Law, Criminology, Criminalistics and Forensic Disciplines and director of the Criminology and Criminalistics Research Centre at the Faculty of Law, Matej Bel University, Banská Bystrica, Slovak Republic. Prof. Libor Klimek is Visiting Professor at the Faculty of Law, Leipzig University, Germany. He is advisor of the Constitutional Court of the Slovak Republic and author and member of editorial boards of legal journals EU Law Journal and Štát a právo (State and Law). He has published over 150 publications.

Open Access This chapter is licensed under the terms of the Creative Commons Attribution 4.0 International License (http://creativecommons.org/licenses/by/4.0/), which permits use, sharing, adaptation, distribution and reproduction in any medium or format, as long as you give appropriate credit to the original author(s) and the source, provide a link to the Creative Commons licence and indicate if changes were made.

The images or other third party material in this chapter are included in the chapter's Creative Commons licence, unless indicated otherwise in a credit line to the material. If material is not included in the chapter's Creative Commons licence and your intended use is not permitted by statutory regulation or exceeds the permitted use, you will need to obtain permission directly from the copyright holder. 